\title{
UNIVERSITY STATUS-AFTER 30 YEARS.
}

(Leader, Potchefstroom Herald, March 16, 1951).

The extensive ceremonies this week-end in connection with the elevation of the Potchefstroom University College to the full status of an independent University are of considerable significance not only to Potchefstroom and the Transvaal but also in the wider field of South Africa, where Christian Higher Education in the Afrikaans medium is of very great interest and importance. The history of the Potchefstroom University, evolved as it has from the establishment here of the Theological College many years ago, has been one of constant struggle for the maintenance of Christian ideals in education and of eventual achievement, often in the face of lack of finance and other difficulties, of principles which are dear to the hearts and sentiments of a large section of the Alrikander people. Apart from the fact that generous monetary contributions have been made from widespread sources, the institution owes much of the progress it has made to the remarkable talents and influence of the late Dr. Ferdinand Postma, whose lamented death a few months ago prevented him from seeing the ultimate success of the strenuous endeavours, over a long period, of himself and those who collaborated with him in the progressive march of the Potchefstroom 
University College towards its goal of full independence. Memories of the indomitable spirit of the late Dr. Postma will doubtless be in the minds of all who are associating themselves in these few notable days with celebrations which mark the victorious end to a lengthy period of devoted labour. The presence in Potchefstroom for the inaugural events of three Cabinet Ministers stresses the importance which the Government attaches to the occasion and is an earnest of the future development of the institution. The establishment in Potchefstroom first of the Theological College-which is at this juncture extending its influence and operations in a big building scheme now being brought into being-combined with the siting and extension of the University buildings in a setting which promises to become one of great beauty-have not only added to the many fine educational structures which are such a feature of Potchefstroom but crystallise the ambition and sentiments of those who have in any way contributed to bringing the faithful work of many years to fruition in this Year of Grace, 1951. In extending on behalf of the local public good wishes for the continued advancement of the now independent University, we hope that under its enhanced status the institution will closely identify itself with the cultural, artistic and social life of Potchefstroom which is more and more being translated into one of South Africa's most notable and virile centres of education, thanks to the sympathetic attitude of successive governments. 